\section{BONAZZI, Mauro; SCHORN, Stefan. Bios Philosophos: Philosophy in Ancient Greek Biography. Turnhout: Brepols, 2016. 313p. ISBN 978-2-503-56546-0}

\author{
Gustavo Laet Gomes* \\ Bernardo C. D. A. Vasconcelos**
}

Bios Philosophos. Philosopby in Ancient Greek Biography (Brepols, 2016), organized by Mauro Bonazzi and Stefan Schorn, delivers a both deep and wide tour through the philosophical aspects of Greek biographical production. On one hand, it does not concentrate only in the later periods of Greek philosophy, when biographical production abounded, but goes all the way back to the fourth century BCE, when biographical texts were fragmentary and mingled with other styles. On the other, it tries to unveil the philosophical motives in the works of authors who tend to be disregarded as historians, biographers, hagiographers or even as mere fans of the most prominent figures of their own schools.

In our review, we will attempt to give a brief account of the ten articles that make up this volume, which, in turn, will hopefully provide an overview of the different connections between the biographies and biographers and their philosophical motives.

Thomas Bénatouil's Pythagore chez. Dicéarque: anectodes biographiques et critique de la philosophie contemplative (p. 11-36) proposes an inversion of the traditional interpretation regarding the testimony of Dicaearchus of Messana about the life of Pythagoras. Since antiquity, Dicaearchus' reports tend to be seen as positive, because they present a Pythagoras devoid of mysticism and apparently more interested in practical matters. Bénatouil shows, instead, that there are several evidences pointing in the opposite direction: the way Pythagoras uses of charm and persuasion in his dealings with the citizens of Croton, obtaining their admiration by means of elaborate discourses meticulously prepared to reach each type of audience (elders, women, young people, and even children and barbarians), and the fact that Pythagoras introduced a theory of soul contrary to that of Dicaearchus'. These tenets would actually be very different from Dicaearchus own idea of a practical life, making Pythagoras a perfect counter-example. Bénatouil explores the motivations that underlie Dicaearchus' testimony, who was a close follower of Aristotle and heir
* Mestre em Filosofia pela Universidade Federal de Minas Gerais.guslaet@ gmail.com

** Mestre em Filosofia pela Universidade Federal de Minas Gerais. bernardovasconcelos (a)gmail.com 
to the polemics against the Academics. His testimony on Pythagoras fits perfectly well with his criticism of the excessive elaboration of the Platonic dialogues, as well as his differences with Heraclides Ponticus and the mysticism around the contemplative life. His Pythagoras, devoid of mysticism, legend and inspired speeches is the exact opposite of Heraclides'. The care and neutrality with which Dicaearchus presents his Pythagoras, contrary to what most interpreters (both ancient and modern) see as a realistic ethical model for practical life, reveals only what Bénatouil calls a methodological distance, proper of the accomplished historian he is said to have been.

Philip Sidney Horky, in Empedocles Democraticus: Hellenistic Biography at the Intersection of Philosopby and Politics (p. 37-70), evaluates the political and philosophical engagement of the Hellenistic historian Timaeus of 'Tauromenium from one of Diogenes Laertius' multilayered reports on the political views of Empedocles of Agrigentum. The first layer of Diogenes report is presumably taken from Aristotle's lost work On Poets, where he presents what Horky defines as an anarchist Empedocles - anarchist for Aristotle being someone free in the sense of not being subject to any sort of rule. Aristotle's Empedocles is a braggart who, claiming divinity, believes to be more than human, and so not required to be involved in political matters. The second layer is the testimony of Xanthus of Lydia, a Sicilian historian who was a contemporary of Empedocles. He reports that Empedocles gave up kingship to live a simple life as a man of the people. Xanthus' Empedocles resembles a Pythagorean and is very different from the anarchist of Aristotle: a man who gives up power to live a simple and common life among his companions. Finally, the Empedocles of Timaeus of Tauromenium is an accomplished democrat, deeply involved in politics, who works to expose a coup attempt to install a tyranny in Agrigentum. According to Horky, the account of Timaeus is not independent of those of Aristotle and Xanthus. He actually draws from both sources dialectically. He explains why Xanthus classify Empedocles as a man of the people by actually depicting him as the opposite of Aristotle's anarchist: an active defender of democracy.

Dino De Sanctis' La biografia del Kũ $\pi$ s e e il profilo esemplare del saggio epicureo (p. 71-99) presents two exemplars of Epicurean biographies extracted from the Herculaneum papyri: the two books On Epicurus from Philodemus of Gadara, and the Life of Pbilonides of Laodicea (whose authorship some scholars attribute to Philodemus as well). De Sanctis' goal is to show the particulars of Epicurean biographies and how they differ from the Peripatetic biography style. Peripatetic biographies are mostly anecdotal, concentrating on minimal events, some intended to praise the protagonists, some not so praiseworthy (which is supposed to produce an air of neutrality). Epicurean biography, on the other hand, is a construction that focuses on the tenets of the Epicurean School and the figure of the master-Epicurus - depicted as a proto-philosopher, a model of ethical conduct. Its purpose is clearly to keep the doctrinal identity and the cohesion of the School. While Philodemus' On Epicurus deals with the good character of the master himself, the Life of Philonides depicts a Philonides that is so close to the master that ends up being a sort of "alter Epicurus", in the words of De Sanctis, who shows that this type of reference to the master is also present in other instances of Epicurean 
biography. The idea of a proto-philosopher goes back to Socrates between his followers (especially the Socrates of the Apology and of the Phaedo, and the Socrates of Xenophon). Yet, different from the dialogical relationship Socrates established with his followers (also called friends, as among the Epicureans), in the Garden, the teachings of the master are not subject to questioning. This unconditional adhesion has the therapeutic goal of providing a tranquil life and is attested by the lives of renowned Epicureans.

Jan Opsomer, in Plutarch's Unphilosophical Lives: Philosophical, after All? (p. 101-126), starts from the apparently trivial question of why Plutarch does not include biographies of philosophers in his Lives to demonstrate how philosophical Plutarch's Lives are after all. Plutarch preferred characters are almost exclusively statesmen: politicians, lawgivers, generals, emperors. What he emphasized in these characters are their actions, especially how they relate to virtue, for good and for evil. Wouldn't it be in the interest of his moralizing project to include a few philosophers - who, after all, are proposers of ethical theories and values - as his champions of virtue (or failures, for all that matters)? Opsomer offers some conjectures on what could have been Plutarch's reasons for preferring practical men instead of philosophers. In the case of philosophers, for instance, underneath the straightforward consistency between theory and practice is the theory itself. In other works, when dealing with Epicureans and Stoics, Plutarch indicates that their theories, being inconsistent in themselves, cannot produce any sort of consistent practice. Moreover, the lives of men engaged in activities with a strong practical side tend to be richer as examples of conduct, even in the application of philosophical principles, which, when they possess, they usually take as laws of conduct, and not theoretical questions. Overall, Plutarch's lives are actually full of philosophical questions and of philosophers too, even if not in the protagonist roles. As for his subjects, he selects them according to character traits he wants to explore, with the goal to produce models of conduct with which people can identify themselves and even emulate. He seems to think that this brings his readers nearer to the philosophical teachings he wants to convey: here are some normal people, albeit famous, who can live according to virtue, even if they are not philosophers.

In The Spectacle of Life: Biography as Pbilosophy in Lucian (p. 127-155), Karin Schlapbach shows how biography is a fundamental instrument for Lucian's approach to philosophy. Although none of Lucian's works can be classified strictly as biographies, many of them contain biographical information (about historical and fictitious characters). Schlapbach chooses three paradigmatic works that draw substantially from the biographical style: Nigrinus' Philosophy, The Life of Demonax and The Death of Peregrinus, portraying philosophers (or a would-be philosopher, in the case of Peregrinus). According to Schlapbach, in his portrayal of philosophers, Lucian introduces a third level of complexity to the overall established topos of the harmony between discourse (logos) and way of life (bios). This third element are gnomai, thoughts and intentions that underlie a philosopher's (or a would-be philosopher's) actions and discourses. Thus, she analyzes the interactions between these three factors - actions, discourses and underlying intentions - in those three works, and what are the strategies that Lucian adopt to explore the dynamics between those three factors, revealing 
how actions are used as discourse and how discourses are actions. This means that actions themselves do not reveal a way of life derivative from one's discourses, but are actually part of the communicative strategy of both philosophers and posers. Consequently, actions do not reveal thoughts (gnomai) in an unambiguous way, as no kind of expression is free of ambiguity. This reveals the active role of the interpreter in Lucian, for he is crucial for the establishment of the philosophical message. It also reveals how biography is fundamental for Lucian's approach to philosophy since it provides context for the interpretation of the philosophical discourse.

In Biographie und Fürstenspiegel. Politische Paränese in Philostrats Vita Apollonii (p. 157195), Stefan Schorn shows that, contrary to the general tendency to disregard Philostratus' Vita Apollonii as a mere sample of ancient romance, relevant only in discussions about fiction in antiquity or as a testimony of Greek identity in the third century CE, Philostratus' work features an interesting dialogue with different philosophical-exhortative traditions. In order to explicit this dialogue, Schorn builds upon the previous work of Flinterman (1995), which analyzed Apollonius' exchange with Vespasian, and sets out to do the same with the remaining exchanges between the main-character, himself a Pythagorean philosopher, and the other kings, namely Vardanes I of Parthia, Phraotes and an Indian king whose name is not provided. In these exchanges, exhortation comes as warnings with the goal of establishing an ethics of government or in the form clarifications regarding state and social theories. The three kings react to Apollonius differently, resulting in different appreciations of their capacity to rule and the level of apprehension of philosophy that each paradigmatic type is capable. Schorn's goal, then, is twofold: eliciting the monarchic theory at play in each exchange and the philosophical exhortative tradition to which if belongs. His hypothesis is that each exchange features a different paradigm of mirror of princes. Interestingly, he points out in the end, there is in the text a clear split between the way of life that can be practiced by philosophers and rulers; and, therefore, a refusal of the Pythagorean thesis according to which the king must live like a philosopher. The kings can't be considered wise, and the one who is de facto wise, is not a ruler. Building upon the depth of exchange and the advices Apollonius offers to each different king, Schorn believes that underlying the play of historical and literary elements there is a deep and legitimate philosophical question: what types of rulers can be influenced by philosophy and to what extent?

In Zwischen Polemik und Hagiographie: Iamblichs De vita Pythagorica im Vergleich mit Porphyrios' Vita Plotini (p. 197-220), Irmgard Männlein-Robert analyzes Iamblichus'Vita Pythagorica in the context of the biographies and hagiographies of the imperial period. The author seeks to investigate whether Iamblichus' Vita Pythagorica is in polemic against another work; and, if so, against which one. Männlein-Robert focuses on the hypothesis that Iamblichus polemic is directed against Porphyry's Vita Plotinii, which has interesting similarities to Iamblichus' work, for both are structured as hagiographic introductions to the lives of their respective protagonists, containing the program of their philosophies and the way of life they advocate. According to Männlein-Robert, each of these biographies reveals a certain point of view within the Platonic philosophy. While Porphyry selects a 
contemporary author, revealing a sort of new tendency, Iamblichus, more conservatively, chooses a legendary figure, which allows him to highlight certain archaic aspects of Platonism and the religious practices he associates with Pythagoras. The polemic, however, is not explicit; it appears in the literary characterization of each work, and in the hagiographical styling of the protagonists and their way of life.

In Depicting the Character of Philosophers: Traces of the Neoplatonic Scale of Virtues in Eunapius' Collective Biography (p. 221-258), Matthias Becker presents evidences of the presence of Neoplatonic scales of virtues in the Lives of the Philosophers and Sophists, a collective biography written around 400 CE by Eunapius of Sardis, decades before Marinus' Life of Proclus, where scales of virtue were explicitly declared "a method of biographical edification". In Eunapius' work, Becker finds clear parallels with all the six kinds of virtue present in the Life of Proclus: natural virtues, which evince how the excellence of the soul manifests itself through the physical constitution of philosophers; ethical virtues, which are qualities of disposition; political virtues, the characteristics of an excellent man; purificatory virtues, which relate to the process of the soul's separation from the body; theoretical virtues, related to intellectual perfection; and theurgic virtues, which relate to the telos of deification of the philosopher. According to Becker, Eunapius applies these virtues in a hierarchical form culminating with the theurgic virtues, indicating adherence to Iamblichus' hierarchy of virtues, which ultimately aims at the soul's unification with God. By presenting these virtues across multiple biographies, Eunapius creates a sort of mosaic of the ideal philosopher, which excels in all virtues of the scale, drawing from different particular lives that excel in the different virtues.

In Il filosofo platonico secondo Damascio (p. 259-274), Franco Trabattoni presents the ideal of the Platonic philosopher according to Damascius of Damascus, the last scholarch of the Academy, as depicted in the extant fragment of his Life of Isidore. Different from other biographical works, the Life of Isidore (whose title is actually a reconstruction) is not only about the character of Isidore, Damascius master and precursor as the head of the Academy, but mentions other characters as well, which helps to form Damascius' ideal of philosopher. In this sense, it has similarities with the Lives of Eunapius, including the fact that it is not strictly a hagiographic work, but contain a certain level of philosophical criticism. For Damascius, whose problem is to stand against the inexorable advancement of Christianity, it was not sufficient to continue presenting a few exceptional characters (as in previous Neoplatonic biographies), but to show how Platonic philosophy was capable of continuing and advancing ancient Greek philosophical knowledge. Hence, it is important for him to show that the fate of the Platonic philosophy is not dependent on particular exceptional characters, such as Isidore or his priors, but that an Isidore can beget a Damascius, who can beget yet another philosopher just as good as or even better than the others. Damascius' ideal philosopher is, of course, connected to the divine, as is the case with all Neoplatonic heroes, but for him, the indexes of this divine relationship manifest themselves in humane characteristics. The ideal philosopher is someone who possesses a number of ethical, moral, and intellectual virtues that ultimately work for the good of those who live around him. 
In this sense, according to Trabattoni, Damascius' ideal philosopher is more Platonic than Neoplatonic, for the divine reveals itself as what is the maximum level achievable for a human being, and not in a transfiguration of man into God during his lifetime. This does not mean that Damascius rejects the divine tenets of Neoplatonism. He certainly believes in the supernatural and praises theurgic virtues, but he seems to believe that the final mingling of men with the divine happens only after death, while in life the philosopher must move according to human possibilities.

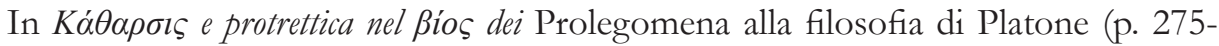
308), Mauro Regali compares the anonymous work Prolegomena to Platonic Pbilosophy with Olympiodorus' biographical accounts of the life of Plato in his comment to First Alcibiades, detailing important differences between the two accounts of the life of Plato and emphasizing the several innovations introduced by the author of the Prolegomena. According to Regali, the Prolegomena clearly have a protreptic character developed around the divine origin of

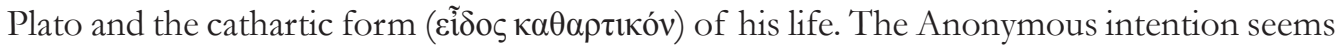
to be to show to an eventual student how Plato embodies all of the Neoplatonic virtues (of the scale of virtues) in order to guide him through his studies of the dialogues. Regali enters into the details of 15 different aspects in which the Anonymous' life either modifies the accounts of Olympiodorus (especially his interpretations of the narrated anecdotes) or literally introduces new elements or even completely new anecdotes that reinforce his goal of proving the divine origin of Plato and the purifying character of his life. This, in its turn, is clearly aligned with the purification themes found in the Phaedo, who, for the Neoplatonists, depicts the philosophical life as a purification process to release the soul from the bonds of the body and the sensible world.

Bios Pbilosophos' articles, then, cover all periods of Ancient Greek Philosophy and succeeds in forming a unity centered on the ethical and political aspects of the philosophical thinking of the biographees throughout the different traditions. The apparent imbalance towards biographies of characters related to Pythagoreanism and Platonism seems to be due not to a matter of preference, but of availability, biographies having become a central style among Neoplatonist philosophy. Regarding this, we should highlight the authors' focus in extracting the philosophical tenets from texts that sometimes approach the hagiographical style. In this sense, we should also highlight three central articles, the ones about Plutarch's biographies of non-philosophers, Apollonius' dialogues with different kings, and Lucian's use of the biographical style to convey a philosophical discourse. It is not that they surpass the others in quality (for all of them are praiseworthy), but because they capture the very essence of the book's proposal, depicting the central role of bios in the constitution of a philosophical message. 